Media Informatika, Vol. 6, No. 1, Juni 2008, 25-38

ISSN: 0854-4743

\title{
APLIKASI PENGAMBILAN KEPUTUSAN PADA PERENCANAAN PRODUKSI BERDASARKAN TEOREMA BAYES
}

\author{
Sugandi Yahdin' ${ }^{1}$, Syamsuriadi ${ }^{2}$, Yenni Eka Rinni ${ }^{3}$ \\ ${ }^{1}$ Dosen Jurusan Matematika, Fakultas MIPA, Universitas Sriwijaya, Palembang \\ ${ }^{2}$ Dosen Fakultas Ilmu Komputer, Universitas Sriwijaya, Palembang \\ ${ }^{3}$ Alumni Jurusan Matematika, Fakultas MIPA, Universitas Sriwijaya, Palembang
}

\begin{abstract}
ABSTRAK
Pengambilan Keputusan dalam kondisi ketidakpastian dapat menggunakan teorema Bayes, dengan criteria nilai harapan dilakukan denagn iterative sehingga ketelitian dan pendekatan ke keadaan sesungguhnya bisa tercapai, dimana peluangnya mempunyai nilai antara nol dan satu. Dengan menggunakan teorema Bayes pengembangan perusahaan asuransi rayon Wilayah III mempunyai nilai harapan maksimum sebesar 190,35.
\end{abstract}

Kata kunci: teorema Bayes, asuransi

\section{PENDAHULUAN}

Peningkatan Manajemen untuk mengembangkan perusahaan, di antaranya dapat melalui peningkatan sarana dan prasarana serta sumber daya manusia dengan tidak tidak meninggalkankualitas peleyanan terhadap konsumen. Untuk perusahaan yang mempunyai beberapa rayon, maka manajer akan menentukan rayon mana yang harus ia prioritaskan yang dapat menghasilkan keuntungan maksimum.

Pengambilan keputusan dapat diambil dengan memperhatikan: sasaran, tujuan, sejumlah alternative tindakan, resiko atau perolehan dari setiap alternative yang berlainan dan criteria pemilihan yang dapat menjadi keputusan terbaik.

Teorema Bayes digunakn dengan nilai harapan dapat dilakukan terhadap keadaan maksimum atau minimum dengan memperhitungan besarnya perolehan yang dapat terwujud dimana peluangnya mempunyai nilai antara nol dan 1 .

Penelitian ini dilakukan di PT, Asuransi Jiwasraya Wilayah Sumatera Selatan, yang meliputi Rayon Wilayah I, Wilayah II, Wilayah III, Wilayah IV dan Wilayah V. Penelitian ini dilakukan untuk Pengambilan keputusan manejemen yang akan merencanakan pengembangan perusahaan pada salah satu yang pada wilayah sumatera sumatera selatan.

\section{LANDASAN TEORI}

Keputusan adalah suatu kesimpulan dari suatu prases untuk memilih tindakan yang terbaik dari sejumlah alternative yang ada. Pengambilan keputusan adalah prtoses yang mencakup semua pemikiran dan kegiatan yang diperlukan guna membuktikan dan memperlihatkan pilihan yang terbaik. Olehkarena itu, 
teori keputusan juga merupakan suatu teknis analisis yang berkenaan dengan pengambilan keputusan melalui bermacam-macam model (Manik 2003).

Teorema Bayes yang digunakan pada proses pengambilan keputusan tidak terlepas dari teori peluang sebagai konsep dasar. Teorema Bayes dikenal sebagai rumus dasar untuk peluang bersyarat yang tidak bebas.

Proses pengambilan keputusan dengan menggunakan criteria harga harapan sering disebut sebagai prosedur keputusan Bayes tanpa data. Meskipun criteria harga harapan mudah pemakaiannya tetapi mengandung banyak kelemahan diantaranya ditemukan sumber informasi yang pada umumnya didasarkan pada pertimbangan subyektif. Oleh karena itu, pengambilan keputusan sering menyadari perlunya tambahan informasi yang didasarkan pada data sesungguhnya guna membantu proses pengambilan keputusan. Biasanya ada informasi yang menguntungkan dan ada informasi yang merugikan. Oleh karena itu, perlu dilakukan seleksi yang cermat untuk menentukan informasi yang dapat ditentukan taksiran yang lebih realistis dari peluang keadaan sesunguhnya.

Syarat-syarat Teorema Bayes bisa digunakan untuk menentukan pengambilan keputusan, yaitu (Levin dkk, 2002):

1. Berada pada kondisi ketidakpastian (adanya alternatif tindakan)

2. Peluang Prior diketahui dan peluang Posterior dapat ditentukan

3. Peluangnya mempunyai nilai antara nol dan satu.

Misalkan diketahui peluang peubah acak $X$ adalah fungsi $\phi_{i}$ sehingga $\mathrm{P}\left(\mathrm{X} \mid \phi_{i}\right)=0$ merupakan peluang bersyarat dari $\mathrm{X}$ untuk $\phi_{i}=0$, jika diambil harga $x$ sebagai harga khusus dari $X$ bersama-sama dengan $\mathrm{P}\left(\phi_{i}\right)=0$ sebagi peluang awal $\phi_{i}$ maka dapat ditentukan peluang baru $\mathrm{f}$ sebagai fungsi dari $\mathrm{X}$ yang disebut dengan peluang Posterior, yaitu:

$$
\mathrm{P}\left(\phi_{i} \mid \mathrm{X}=\mathrm{x}\right)=\frac{P\left(0_{i^{\prime}} X\right)}{P(X)}
$$

jadi harga harapannya $(\mathrm{HH})$ menjadi:

$$
\mathrm{HH}\left(\mathrm{a}_{1}\right)=\sum(i j) * P\left(\theta_{j} \mid X=x\right)
$$

Keputusan yang diambil disebut keputusan Bayes dengan data. Hal yang perlu diperhatikan adalah bahwa peluang posterior diperoleh dari sample pertama sebagai peluang prior pada stampel kedua dan seterusnya.

Asuransi berarti pertanggungan, dalam suatu asuransi terlibat dua pihak, pihak pertama sebagai penanggung risiko (perusahaan asuransi) dan pihak kedua merupakan tertanggung (nasabah) yang berpotensi mengalami risiko. Tertanggung secara periodic membayar sejumlah dana tertentu yang wajib diserahkan pihak tertanggung kepada pihak asuransi sebagai suatu dana untuk membayar risiko yang mereka miliki (premi asuransi) yang besarnya sesuai dengan kontrak perjanjian yang telah disepakati (polis asuransi). Jadi, asuransi 
jiwa adalah asuransi yang memberikan pembayaran sejumlah uang tertentu atas kematian tertanggung kepada anggota keluarga/orang yang berhak menerimanya sesuai dengan ketentuan dalam polis asuransi.

Risiko pada asuransi merupakan unsur ketidakpastian atas terjadinya suatu peristiwa. Dalam perusahaan asuransi juga memperhatikan unsure peluang (probabilitas), dimana unsure peluang terhadap suatu peristiwa pada masa mendatang belum tentu terjadi sebagaimana yang diperkirakan. Dalam perhitungan asuransi data yang ada mengikuti sebaran normal. Data yang mengikuti sebaran tergantung pada dua parameter yaitu rata-rata dan simpangan baku (Soekarto, 1987).

$$
\begin{aligned}
& \bar{X}=\frac{\sum_{i=1}^{n} i}{n} \\
& s=\sqrt{\frac{\sum_{i=1}^{n}\left(X_{i}-\bar{X}\right)^{2}}{n-1}}
\end{aligned}
$$

dengan:

$\mathrm{S}$ = simpangan baku, $\mathrm{s}^{2}=$ varians

$\mathrm{X}_{1}=$ jumlah penjualan polis

$\bar{X}=$ rata-rata penjualan polis

$\mathrm{n}=$ banyak data

\section{METODOLOGI}

1. Mengumpulkan data sekunder tentang jumlah produksi polis dan nilai jual polis.

2. Melakuakan analisis deskripsi data yang ada.

3. Menghitung nilai rata-rata dan simpangan baku dari data yang ada

4. Memformulasikan permasalahan ke dalam teori keputusan

5. Menentukan keputusan harga harapan yang harus diambil dengan Teorema Bayes dari data yang ada

6. Menganalisa hasil yang diperoleh dan membuat kesimpulan.

\section{HASIL DAN PEMBAHASAN}

\subsection{Deskripsi Data}

Jumlah polis dan nilai jual PT. Asuransi Jiwasraya Wilayah Sumatera Selatan selama tiga tahun terakhir seperti pada Tabel 1. 
Tabel 1. Jumlah dan Nilai Jual Polis Pada Tahun 2001 sampai Tahun 2003 PT. Asuransi Jiwasraya Wilayah Sumatera Selatan

\begin{tabular}{|c|c|c|c|c|c|c|c|}
\hline \multirow{2}{*}{ Rayon } & Periode & Polis & $\begin{array}{c}\text { Nilai } \\
\text { (Rp. } \text { Ribu,-) }\end{array}$ & Polis & $\begin{array}{c}\text { Nilai } \\
\text { (Rp. } \text { Ribu, }\end{array}$ & Polis & $\begin{array}{c}\text { Nilai } \\
\text { (Rp. } \text { Ribu, }\end{array}$ \\
\hline Wilayah I
\end{tabular}

Sumber: PT. Asuransi Jiwasraya Wilayah V

\subsection{Analisis Keputusan}

Proses keputusan dalam melaksanakan kegiatan akan menjadi rumit jika dibuat dalam kondisi ketidakpastian. Pada kenyataannya setiap perencanaan yang di buat kadang sulit memprediksi kejadian pada masa yang akan datang. Untuk itu data-data yang telah terjadi pada masa lalu sangat diperlukan sebagai langkah awal dalam membuat prediksi di masa mendatang.

Dari data jumlah dan nilai jual polis yang ada dapat dilihat adanya tiga kondisi yang bisa dijadikan bahan analisis untuk menduga kejadian yang akan terjadi di masa yang akan datang. Karena tidak ada seorangpun yang dapat menentukan kondisi/kejadian yang akan datang dengan tepat. Berdasarkan data nilai jual polis pada PT. Asuransi Jiwasraya dari itu adalah terjadinya penurunan jumlah penjualan polis artinya penjualan polis sedang memburuk. Jika penjualan polis berada pada nilai rata-rata target artinya penjualan polis dalam kondisi sedang (Stabil). Jika terjadi peningkatan polis dari target semula artinya penjualan polis membaik. Dari data di atas, maka nilai jual polis tersebut selama tiga tahun terakhir dapat diasumsikan:

1. tingkat penjualan polis dengan nilai 40.000 sampai 90.000 artinya terjadi penurunan penjualan polis (memburuk) sebesar $20 \%$. 
2. tingkat penjualan polis dengan nilai di atas 900.000 sampai 1.550 .000 artnya tingkat penjualan polis berada pada rata-rata target (stabil) atau sebesar $50 \%$.

3. tingkat penjualan polis ddi atas 1.550 .000 sampai dengan 22.000 .000 artinya terjadi peningkatan penjualan polis (membaik) atau sebesar $30 \%$.

Berdasarkan data penjualan polis selama tiga tahun terakhir untuk wilayah Sumatera Selatan, diperoleh :rata-rata penjualan polis untuk seluruh kantor rayon 151,72 , simpangan baku 58,648 sedangkan tingkat penjualan polis untuk seluruh rayon pada kondisi $(\theta \mathrm{j})$ yang mungkin terjadi:

1. Tingkat penjualan polis pada saat terjadi penurunan dari nilai rata-rata yang ditargetkan (kondisi memburuk), diasumikan = Rata-rata - simpangan baku = $151,72-58,648=93,07$.

2. Tingkat penjualan polis pada kondisi pada nilai rata-rata stabil diasumsikan Rata-rata penjualan polis $=151,72$.

3. Tingkat penjulan polis pada saat terjadi peningkatan dari nilai rata-rata yang ditargetkan (kondisi membaik), diasumsikan sebagai: $=$ Rata-rata + simpangan baku $=151,72+58,648=210,37$.

Analog dari perhitungan di atas,perhitungan untuk alternative tindakan pada lima kantor rayon juga dilakukan perhitungan sebagai berikut :

1. Menghitung rata-rata tingkat penjualan polis, data yang digunakan hanya data penjualan polis untuk kantor rayon Wilayah I dari tahun 2001-2003 adalah 165,916

2. Menghitung simpangan baku adalah 41,823

3. Menentukan nilai tingkat penjualan polis pada kondisi/keadaan $(\theta j)$ yang mungkin terjadi, hanya untuk kantor rayon Wilayah I

a. Tingkat penjualan polis pada saat terjadi penurunan dari nilai rata-rata yang ditargetkan (kondisi memburuk), diasumsikan sebagai: = Rata-rata simpangan baku $=165,916-41,823=124,09$.

b. Tingkat penjualan polis pada kondisi berada pada nilai rata-rata target (stabil) diasumsikan $=$ Rata-rata penjualan polis $=165,916$.

c. Tingkat penjualan pada saat terjadi peningkatan dari nilai rata-rata yang ditargetkan (kondisi membaik), diasumsikan: = Rata-rata + simpangan baku $=165,916+41,823=207,74$.

Dengan cara yang sama perhitungan dilakukan untuk alternative kantor rayon lainnya, hasil perhitungan secara lengkap disajikan seperti pada Tabel 2.

Pada kondisi ketidakpastian, berbagai kriteria dapat digunakan untuk mengambil keputusan dari beberapa alternative tindakan di atas, yaitu:

\section{a. Kriteria Maximax}

Yaitu kriteria yang berdasarkan pada laba yang maksimum (keputusan optimistis) Kriteria Maximas dapat digambarkan dengan Tabel 3. 
Tabel 2. Perkiraan Awal Tingkat Penjualan Polis PT. Asuransi Jiwasraya Wilayah Sumatera Selatan

\begin{tabular}{|l|c|c|c|}
\hline \multirow{2}{*}{\multicolumn{1}{|c|}{ Alternatif }} & \multicolumn{3}{|c|}{$\theta \mathbf{j}$} \\
\cline { 2 - 4 } & $\mathbf{9 3 , 0 7}$ & $\mathbf{1 5 1 , 7 2}$ & $\mathbf{2 1 0 , 3 7}$ \\
\hline Wilayah I & 124,09 & 165,92 & 207,74 \\
\hline Wilayah II & 122,26 & 164,67 & 207,07 \\
\hline Wilayah III & 116,06 & 190,25 & 264,44 \\
\hline Wilayah IV & 91,19 & 144,33 & 197,47 \\
\hline Wilayah V & 65,41 & 93,42 & 121,42 \\
\hline \multicolumn{1}{|c|}{$\mathbf{P}(\theta \mathbf{j})$} & $\mathbf{0 , 2}$ & $\mathbf{0 , 5}$ & $\mathbf{0 , 3}$ \\
\hline
\end{tabular}

Tabel 3. Payoff untuk kriteria Maximax

\begin{tabular}{|l|c|c|c|}
\hline \multirow{2}{*}{\multicolumn{1}{|c|}{ Alternatif }} & \multicolumn{3}{|c|}{$\theta \mathbf{j}$} \\
\cline { 2 - 4 } & $\mathbf{9 3 , 0 7}$ & $\mathbf{1 5 1 , 7 2}$ & $\mathbf{2 1 0 , 3 7}$ \\
\hline Wilayah I & 124,09 & 165,92 & 207,74 \\
\hline Wilayah II & 122,26 & 164,67 & 207,07 \\
\hline Wilayah III & 116,06 & 190,25 & $\mathbf{2 6 4 , 4 4}$ \\
\hline Wilayah IV & 91,19 & 144,33 & 197,47 \\
\hline Wilayah V & 65,41 & 93,42 & 121,42 \\
\hline
\end{tabular}

\section{b. Kriteria Maximin}

Yaitu kriteria yang berdasaarkan pada laba yang minimum (keputusan pesimistis). Kriteria Maximin dapat digambarkan dengan Tabel 4.

Tabel 4. Payoff untuk kriteria Maximin

\begin{tabular}{|l|c|c|c|}
\hline \multirow{2}{*}{\multicolumn{1}{|c|}{ Alternatif }} & \multicolumn{3}{|c|}{$\theta \mathbf{j}$} \\
\cline { 2 - 4 } & $\mathbf{9 3 , 0 7}$ & $\mathbf{1 5 1 , 7 2}$ & $\mathbf{2 1 0 , 3 7}$ \\
\hline Wilayah I & $\mathbf{1 2 4 , 0 9}$ & 165,92 & 207,74 \\
\hline Wilayah II & 122,26 & 164,67 & 207,07 \\
\hline Wilayah III & 116,06 & 190,25 & 264,44 \\
\hline Wilayah IV & 91,19 & 144,33 & 197,47 \\
\hline Wilayah V & 65,41 & 93,42 & 121,42 \\
\hline
\end{tabular}

\section{c. Kriteria Harga Harapan}

Kriteria harga harapan digambarkan pada Tabel 5.

Tabel 5. Payoff untuk kriteria harga harapan

\begin{tabular}{|l|c|c|c|c|}
\hline \multirow{2}{*}{ Alternatif } & \multicolumn{3}{|c|}{$\theta \mathbf{j}$} & $\begin{array}{c}\text { HH } \\
\text { (Harga Harapan) }\end{array}$ \\
\cline { 2 - 4 } & $\mathbf{9 3 , 0 7}$ & $\mathbf{1 5 1 , 7 2}$ & $\mathbf{2 1 0 , 3 7}$ & 170,10 \\
\hline Wilayah I & 124,09 & 165,92 & 207,74 & 168,91 \\
\hline Wilayah II & 122,26 & 164,67 & 207,07 & $\mathbf{1 9 7 , 6 7}$ \\
\hline Wilayah III & 116,06 & 190,25 & 264,44 & 149,64 \\
\hline Wilayah IV & 91,19 & 144,33 & 197,47 & 96,22 \\
\hline Wilayah V & 65,41 & 93,42 & 121,42 & \\
\hline \multicolumn{1}{|c|}{$\mathbf{P}(\theta \mathbf{j})$} & $\mathbf{0 , 2}$ & $\mathbf{0 , 5}$ & $\mathbf{0 , 3}$ & \\
\hline
\end{tabular}


Berdasarkan kriteria harga harapan maksimum dari alternatif di atas maka pilihannya adalah mengembangkan rayon Wilayah III.

\subsection{Analisis Keputusan dengan Teorema Bayes}

Untuk mendapatkan keputusan dengan teorema Bayes menentukan nilai peluang posterior, dengan fungsi $\theta j$ untuk sebaran normal:

$P\left(X \mid \theta_{j}=\theta\right)=\frac{1}{\sqrt{2 \pi \bullet s}} e^{-\frac{\left(x-\theta_{j}\right)^{2}}{2 s^{2}}}$

Berdasarkan hukum Bayes diperoleh besarnya peluang posterior ke-j sebagai berikut:

$$
p\left(\theta_{j} \mid X=x\right)=\frac{P\left(\theta_{j}\right) \bullet e^{-(0,5)\left\{x-\theta_{j} \mid x\right\}^{2}}}{\sum_{j=1}^{3} P\left(\theta_{j}\right) \bullet e^{-(0,5)\left\{x-\theta_{j} \mid x\right\}^{2}}}
$$

Dengan $\mathrm{P}(\theta \mathrm{j})$ adalah peluang prior dan $\mathrm{x}$ adalah nilai rata-rata sample dari seluruh populasi.

Berdasarkan hasil perhitungan dengan nilai rata-rata umum sebesar 151.172, maka harga harapan yang optimal dapat dilakukan dengan mencari posterior secara iterasi sampai diperoleh nilai peluang posterior. Pilihan alternative yang diambil untuk nilai $\mathrm{HH}$ maksimum:

\section{Iterasi I}

$$
\begin{aligned}
& P\left(\theta_{1}\right) \bullet e^{-(0,5)\left\{x-\theta_{1} \mid \sigma\right\}^{2}}=0,2 \cdot e^{-(0,5)\left\{(151,72-93,07)^{2} / 3439,664\right)}=0,1213 \\
& P\left(\theta_{3}\right) \bullet e^{-(0,5)\left\{x-\theta_{3} \mid \sigma\right\}^{2}}=0,2 \cdot e^{-(0,5)\left\{(151,72-210,37)^{2} / 3439,664\right)}=0,5 \\
& P\left(\theta_{2}\right) \bullet e^{-(0,5)\left\{x-\theta_{2} \mid \sigma\right\}^{2}}=0,2 \cdot e^{-(0,5)\left\{(151,72-151,72)^{2} / 3439,664\right)}=0,1820 \\
& \sum_{j=1}^{3} P\left(\theta_{j}\right) \bullet e^{-(0,5)\left\{x-\theta_{j} \mid \sigma\right\}^{2}}=0,123+0,5+0,1820=0,8033 \\
& \text { Besarnya peluang posterior ke-1 adalah: } 0,123 / 0,8033=0,1510 \\
& \text { Besarnya peluang posterior ke-2 adalah: } 0,5 / 0,8033=0,6224 \\
& \text { Besarnya peluang posterior ke-3 adalah: } 0,1820 / 0,8033=0,2265
\end{aligned}
$$

\begin{tabular}{|c|c|c|c|c|}
\hline \multirow{2}{*}{ Alternatif } & \multicolumn{3}{|c|}{$\theta j$} & \multirow{2}{*}{$\begin{array}{c}\text { HH } \\
\text { (Harga Harapan) }\end{array}$} \\
\hline & 93,07 & 151,72 & 210,37 & \\
\hline Wilayah I & 124,09 & 165,92 & 207,74 & 169,06 \\
\hline Wilayah II & 122,26 & 164,67 & 207,07 & 167,85 \\
\hline Wilayah III & 116,06 & 190,25 & 264,44 & 195,83 \\
\hline Wilayah IV & 91,19 & 144,33 & 197,47 & 148,33 \\
\hline Wilayah V & 65,41 & 93,42 & 121,42 & 96,52 \\
\hline $\mathbf{P}(\theta j)$ & 0,1510 & 0,6224 & 0,2265 & \\
\hline
\end{tabular}

Setelah nilai peluang posterior diperoleh, maka data pada Tabel 5 dibentuk menjadi Tabel 6 dan dicari harga harapan untuk masing-masing alternatif tindakan.

Tabel 6. Hasil Iterasi I Analisis dengan Teorema Bayes 
Iterasi II.

- $P\left(\theta_{3}\right) \bullet e^{-(0,5)\left\{x-\theta_{3} \mid \sigma\right\}^{2}}=0,2265 \cdot e^{-(0,5)\left\{(151,72-210,37)^{2} / 3439,664\right)}=0,0916$

- $P\left(\theta_{1}\right) \bullet e^{-(0,5)\left\{x-\theta_{1} \mid \sigma\right\}^{2}}=0,1510 \cdot e^{-(0,5)\left\{(151,72-93,07)^{2} / 3439,664\right)}=0,6224$

- $P_{3}\left(\theta_{2}\right) \bullet e^{-(0,5)\left\{x-\theta_{2} \mid \sigma\right\}^{2}}=0,6224 . e^{-(0,5)\left\{(151,72-151,72)^{2} / 3439,664\right)}=0,1374$

- $\sum_{j=1} P\left(\theta_{j}\right) \bullet e^{-(0,5)\left\{x-\theta_{j} \mid \sigma\right\}^{2}}=0,0916+0,6224+0,1374=0,8514$

Besarnya peluang posterior ke-1 adalah: 0,0916 /0,8514 $=0,1069$

Besarnya peluang posterior ke-2 adalah: 0,6224 $/ 0,8514=0,7316$

Besarnya peluang posterior ke-3 adalah: 0,1374 /0,8514 =0,1615

Setelah nilai peluang posterior diperoleh dan dicari harga harapan untuk masing-masing alternatif tindakan, hasilnya disajikan pada Tabel 7.

Tabel 7. Hasil Iterasi I Analisis dengan Teorema Bayes.

\begin{tabular}{|l|c|c|c|c|}
\hline \multirow{2}{*}{ Alternatif } & \multicolumn{3}{|c|}{$\theta \mathbf{j}$} & $\begin{array}{c}\text { HH } \\
\text { (Harga Harapan) }\end{array}$ \\
\cline { 2 - 4 } & $\mathbf{9 3 , 0 7}$ & $\mathbf{1 5 1 , 7 2}$ & $\mathbf{2 1 0 , 3 7}$ & 168,20 \\
\hline Wilayah I & 124,09 & 165,92 & 207,74 & 166,98 \\
\hline Wilayah II & 122,26 & 164,67 & 207,07 & $\mathbf{1 9 4 , 3 0}$ \\
\hline Wilayah III & 116,06 & 190,25 & 264,44 & 147,23 \\
\hline Wilayah IV & 91,19 & 144,33 & 197,47 & 94,95 \\
\hline Wilayah V & 65,41 & 93,42 & 121,42 & \\
\hline \multicolumn{1}{|c|}{$\mathbf{P}(\theta \mathbf{j})$} & $\mathbf{0 , 1 0 6 9}$ & $\mathbf{0 , 7 3 1 6}$ & $\mathbf{0 , 1 6 1 5}$ & \\
\hline
\end{tabular}

\section{Iterasi III.}

- $P\left(\theta_{1}\right) \bullet e^{-(0,5)\left\{x-\theta_{1} \mid \sigma\right\}^{2}}=0,1069 \cdot e^{-(0,5)\left\{(151,72-93,07)^{2} / 3439,664\right)}=0,0652$

- $P\left(\theta_{2}\right) \bullet e^{-(0,5)\left\{x-\theta_{2} \mid \sigma\right\}^{2}}=0,7316 . e^{-(0,5)\left\{(151,72-151,72)^{2} / 3439,664\right)}=0,7311$

- $P\left(\theta_{3}\right) \bullet e^{-(0,5)\left\{x-\theta_{3} \mid \sigma\right\}^{2}}=0,1615 \cdot e^{-(0,5)\left\{(151,72-210,37)^{2} / 3439,664\right)}=0,0979$

- $\sum_{j=1}^{3} P\left(\theta_{j}\right) \bullet e^{-(0,5)\left\{x-\theta_{j} \mid \sigma\right\}^{2}=} \quad 0,0652+0,7311+0,0979 \quad=0,8942$

Besarnya peluang posterior ke-1 adalah: 0,0652 / 0,8942 =0,0730

Besarnya peluang posterior ke-2 adalah: 0,7311 / 0,8942 $=0,8176$

Besarnya peluang posterior ke-3 adalah: 0,0979 / 0,8942 = 0,1094

Setelah nilai peluang posterior diperoleh dan dicari harga harapan untuk masing-masing alternatif tindakan, hasilnya disajikan pada Tabel 8. 
Tabel 8. Hasil Iterasi I Analisis dengan Teorema Bayes.

\begin{tabular}{|l|c|c|c|c|}
\hline \multirow{2}{*}{ Alternatif } & \multicolumn{3}{|c|}{$\theta \mathbf{j}$} & $\begin{array}{c}\text { HH } \\
\text { (Harga Harapan) }\end{array}$ \\
\cline { 2 - 4 } & $\mathbf{9 3 , 0 7}$ & $\mathbf{1 5 1 , 7 2}$ & $\mathbf{2 1 0 , 3 7}$ & 167,45 \\
\hline Wilayah I & 124,09 & 165,92 & 207,74 & 166,22 \\
\hline Wilayah II & 122,26 & 164,67 & 207,07 & $\mathbf{1 9 2 , 9 6}$ \\
\hline Wilayah III & 116,06 & 190,25 & 264,44 & 146,27 \\
\hline Wilayah IV & 91,19 & 144,33 & 197,47 & 94,44 \\
\hline Wilayah V & 65,41 & 93,42 & 121,42 & \\
\hline \multicolumn{1}{|c|}{$\mathbf{P}(\theta \mathbf{j})$} & $\mathbf{0 , 0 7 3 0}$ & $\mathbf{0 , 8 1 7 6}$ & $\mathbf{0 , 1 0 9 4}$ & \\
\hline
\end{tabular}

Iterasi IV.

$$
\begin{aligned}
& \text { - } P\left(\theta_{1}\right) \bullet e^{-(0,5)\left\{x-\theta_{1} \mid \sigma\right\}^{2}}=0,0730 \cdot e^{-(0,5)\left\{(151,72-93,07)^{2} / 3439,664\right)}=0,0443 \\
& \text { - } P\left(\theta_{2}\right) \bullet e^{-(0,5)\left\{x-\theta_{2} \mid \sigma\right\}^{2}}=0,8176 . e^{-(0,5)\left\{(151,72-151,72)^{2} / 3439,664\right)}=0,8176 \\
& \text { - } P\left(\theta_{3}\right) \bullet e^{-(0,5)\left\{x-\theta_{3} \mid \sigma\right\}^{2}}=0,1094 \cdot e^{-(0,5)\left\{(151,72-210,37)^{2} / 3439,664\right)}=0,0664 \\
& \text { - } \sum_{j=1}^{3} P\left(\theta_{j}\right) \bullet e^{-(0,5)\left\{x-\theta_{j} \mid \sigma\right\}^{2}}=0,0443+0,8176+0,0664=0,9282
\end{aligned}
$$

Besarnya peluang posterior ke-1 adalah: 0,0443 / 0,9282 $=0,0447$

Besarnya peluang posterior ke-2 adalah: 0,8176 / 0,9282 $=0,8808$

Besarnya peluang posterior ke-3 adalah: 0,0664 / 0,9282 =0,0715

Setelah nilai peluang posterior diperoleh dan dicari harga harapan untuk masing-masing alternatif tindakan, hasilnya disajikan pada Tabel 9.

Tabel 9. Hasil Iterasi I Analisis dengan Teorema Bayes.

\begin{tabular}{|l|c|c|c|c|}
\hline \multirow{2}{*}{ Alternatif } & \multicolumn{3}{|c|}{$\theta \mathbf{j}$} & $\begin{array}{c}\text { HH } \\
\text { (Harga Harapan) }\end{array}$ \\
\cline { 2 - 4 } & $\mathbf{9 3 , 0 7}$ & $\mathbf{1 5 1 , 7 2}$ & $\mathbf{2 1 0 , 3 7}$ & 166,92 \\
\hline Wilayah I & 124,09 & 165,92 & 207,74 & 165,68 \\
\hline Wilayah II & 122,26 & 164,67 & 207,07 & $\mathbf{1 9 2 , 0 2}$ \\
\hline Wilayah III & 116,06 & 190,25 & 264,44 & 145,60 \\
\hline Wilayah IV & 91,19 & 144,33 & 197,47 & 94,09 \\
\hline Wilayah V & 65,41 & 93,42 & 121,42 & \\
\hline \multicolumn{1}{|c|}{$\mathbf{P}(\boldsymbol{\theta} \mathbf{j})$} & $\mathbf{0 , 0 4 4 7}$ & $\mathbf{0 , 8 8 0 8}$ & $\mathbf{0 , 0 7 1 5}$ & \\
\hline
\end{tabular}

\section{Iterasi V.}

- $P\left(\theta_{1}\right) \bullet e^{-(0,5)\left\{x-\theta_{1} \mid \sigma\right\}^{2}}=0,0447 \cdot e^{-(0,5)\left\{(151,72-93,07)^{2} / 3439,664\right)}=0,0289$

- $P\left(\theta_{2}\right) \bullet e^{-(0,5)\left\{x-\theta_{2} \mid \sigma\right\}^{2}}=0,8808 \cdot e^{-(0,5)\left\{(151,72-151,72)^{2} / 3439,664\right)}=0,8808$

- $P\left(\theta_{3}\right) \bullet e^{-(0,5)\left\{x-\theta_{3} \mid \sigma\right\}^{2}}=0,0715 \cdot e^{-(0,5)\left\{(151,72-210,37)^{2} / 3439,664\right)}=0,0434$

- $\sum_{j=1}^{3} P\left(\theta_{j}\right) \bullet e^{-(0,5)\left\{x-\theta_{j} \mid \sigma\right\}^{2}}=0,0289+0,8808+0,0434=0,9531$ 
Besarnya peluang posterior ke-1 adalah: 0,0289 $/ 0,9531=0,0313$

Besarnya peluang posterior ke-2 adalah: $0,8808 / 0,9531=0,9242$

Besarnya peluang posterior ke-3 adalah: 0,0434 /0,9531 $=0,0455$

Setelah nilai peluang posterior diperoleh dan dicari harga harapan untuk masing-masing alternatif tindakan, hasilnya disajikan pada Tabel 10.

Tabel 10. Hasil Iterasi I Analisis dengan Teorema Bayes.

\begin{tabular}{|l|c|c|c|c|}
\hline \multirow{2}{*}{ Alternatif } & \multicolumn{3}{|c|}{$\theta \mathbf{j}$} & $\begin{array}{c}\text { HH } \\
\text { (Harga Harapan) }\end{array}$ \\
\cline { 2 - 4 } & $\mathbf{9 3 , 0 7}$ & $\mathbf{1 5 1 , 7 2}$ & $\mathbf{2 1 0 , 3 7}$ & 166,55 \\
\hline Wilayah I & 124,09 & 165,92 & 207,74 & 165,31 \\
\hline Wilayah II & 122,26 & 164,67 & 207,07 & $\mathbf{1 9 1 , 3 8}$ \\
\hline Wilayah III & 116,06 & 190,25 & 264,44 & 145,14 \\
\hline Wilayah IV & 91,19 & 144,33 & 197,47 & 93,84 \\
\hline Wilayah V & 65,41 & 93,42 & $\mathbf{1 2 1 , 4 2}$ & \\
\hline \multicolumn{1}{|c|}{$\mathbf{P}(\boldsymbol{\theta j})$} & $\mathbf{0 , 0 3 0 3}$ & $\mathbf{0 , 9 2 4 2}$ & $\mathbf{0 , 0 4 5 5}$ & \\
\hline
\end{tabular}

Iterasi VI.

- $P\left(\theta_{1}\right) \bullet e^{-(0,5)\left\{x-\theta_{1} \mid \sigma\right\}^{2}}=0,0303 \cdot e^{-(0,5)\left\{(151,72-93,07)^{2} / 3439,664\right)}=0,0184$
- $P\left(\theta_{2}\right) \bullet e^{-(0,5)\left\{x-\theta_{2} \mid \sigma\right\}^{2}}=0,9242 \cdot e^{-(0,5)\left\{(151,72-151,72)^{2} / 3439,664\right)}=0,9242$
- $P\left(\theta_{3}\right) \bullet e^{-(0,5)\left\{x-\theta_{3} \mid \sigma\right\}^{2}}=0,0455 \cdot e^{-(0,5)\left\{(151,72-210,37)^{2} / 3439,664\right)=0,0276}$
- $\sum_{j=1}^{3} P\left(\theta_{j}\right) \bullet e^{-(0,5)\left\{x-\theta_{j} \mid \sigma\right\}^{2}}=0,0184+0,9242+0,0276=0,9702$

Besarnya peluang posterior ke-1 adalah: 0,0184 / 0,9702 =0,0190

Besarnya peluang posterior ke-2 adalah: 0,9242 / 0,9702 =0,9526

Besarnya peluang posterior ke-3 adalah: 0,0276 / 0,9702 = 0,0284

Setelah nilai peluang posterior diperoleh dan dicari harga harapan untuk masing-masing alternatif tindakan, hasilnya disajikan pada Tabel 11.

Tabel 11. Hasil Iterasi I Analisis dengan Teorema Bayes.

\begin{tabular}{|l|c|c|c|c|}
\hline \multirow{2}{*}{ Alternatif } & \multicolumn{3}{|c|}{$\theta \mathbf{j}$} & $\begin{array}{c}\text { HH } \\
\text { (Harga Harapan) }\end{array}$ \\
\cline { 2 - 4 } & $\mathbf{9 3 , 0 7}$ & $\mathbf{1 5 1 , 7 2}$ & $\mathbf{2 1 0 , 3 7}$ & 166,32 \\
\hline Wilayah I & 124,09 & 165,92 & 207,74 & 165,07 \\
\hline Wilayah II & 122,26 & 164,67 & 207,07 & $\mathbf{1 9 0 , 9 5}$ \\
\hline Wilayah III & 116,06 & 190,25 & 264,44 & 144,83 \\
\hline Wilayah IV & 91,19 & 144,33 & 197,47 & 93,68 \\
\hline Wilayah V & 65,41 & 93,42 & 121,42 & \\
\hline \multicolumn{1}{|c|}{$\mathbf{P}(\theta \mathbf{j})$} & $\mathbf{0 , 0 1 9 0}$ & $\mathbf{0 , 9 5 6 2}$ & $\mathbf{0 , 0 2 8 4}$ & \\
\hline
\end{tabular}




\section{Iterasi VII.}

- $P\left(\theta_{1}\right) \bullet e^{-(0,5)\left\{x-\theta_{1} \mid \sigma\right\}^{2}}=0,0190 \cdot e^{-(0,5)\left\{(151,72-93,07)^{2} / 3439,664\right)}=0,0115$

- $P\left(\theta_{2}\right) \bullet e^{-(0,5)\left\{x-\theta_{2} \mid \sigma\right\}^{2}}=0,9526 \cdot e^{-(0,5)\left\{(151,72-151,72)^{2} / 3439,664\right)}=0,9526$

- $P\left(\theta_{3}\right) \bullet e^{-(0,5)\left\{x-\theta_{3} \mid \sigma\right\}^{2}}=0,0284 . e^{-(0,5)\left\{(151,72-210,37)^{2} / 3439,664\right)}=0,0172$

- $\sum_{j=1}^{3} P\left(\theta_{j}\right) \bullet e^{-(0,5)\left\{x-\theta_{j} \mid \sigma\right\}^{2}}=0,0115+0,9526+0,0172=0,9813$

Besarnya peluang posterior ke-1 adalah: 0,0115 /0,9813 =0,0117

Besarnya peluang posterior ke-2 adalah: $0,9526 / 0,9813=0,9707$

Besarnya peluang posterior ke-3 adalah: 0,0172 /0,9813 =0,0176

Setelah nilai peluang posterior diperoleh dan dicari harga harapan untuk masing-masing alternatif tindakan, hasilnya disajikan pada Tabel 12.

Tabel 12. Hasil Iterasi I Analisis dengan Teorema Bayes.

\begin{tabular}{|l|c|c|c|c|}
\hline \multirow{2}{*}{\multicolumn{1}{|c|}{ Alternatif }} & \multicolumn{3}{|c|}{$\theta \mathbf{j}$} & $\begin{array}{c}\text { HH } \\
\text { (Harga Harapan) }\end{array}$ \\
\cline { 2 - 4 } & $\mathbf{9 3 , 0 7}$ & $\mathbf{1 5 1 , 7 2}$ & $\mathbf{2 1 0 , 3 7}$ & 166,16 \\
\hline Wilayah I & 124,09 & 165,92 & 207,74 & 164,92 \\
\hline Wilayah II & 122,26 & 164,67 & 207,07 & $\mathbf{1 9 0 , 6 8}$ \\
\hline Wilayah III & 116,06 & 190,25 & 264,44 & 144,64 \\
\hline Wilayah IV & 91,19 & 144,33 & 197,47 & 93,58 \\
\hline Wilayah V & 65,41 & 93,42 & 121,42 & \\
\hline \multicolumn{1}{|c|}{$\mathbf{P}(\boldsymbol{\theta} \mathbf{j})$} & $\mathbf{0 , 0 1 1 7}$ & $\mathbf{0 , 9 7 0 7}$ & $\mathbf{0 , 0 1 7 6}$ & \\
\hline
\end{tabular}

\section{Iterasi VIII.}

- $P\left(\theta_{1}\right) \bullet e^{-(0,5)\left\{x-\theta_{1} \mid \sigma\right\}^{2}}=0,0117 \cdot e^{-(0,5)\left\{(151,72-93,07)^{2} / 3439,664\right)}=0,0071$

- $P\left(\theta_{2}\right) \bullet e^{-(0,5)\left\{x-\theta_{2} \mid \sigma\right\}^{2}}=0,9707 . e^{-(0,5)\left\{(151,72-151,72)^{2} / 3439,664\right)}=0,9707$

- $P\left(\theta_{3}\right) \bullet e^{-(0,5)\left\{x-\theta_{3} \mid \sigma\right\}^{2}}=0,0176 \cdot e^{-(0,5)\left\{(151,72-210,37)^{2} / 3439,664\right)}=0,0107$

- $\quad \sum_{j=1}^{3} P\left(\theta_{j}\right) \bullet e^{-(0,5)\left\{x-\theta_{j} \mid \sigma\right\}^{2}}=0,0071+0,9707+0,0107=0,9885$

Besarnya peluang posterior ke-1 adalah: 0,0071 /0,9885 $=0,0072$

Besarnya peluang posterior ke-2 adalah: $0,9707 / 0,9885=0,9820$

Besarnya peluang posterior ke-3 adalah: $0,0107 / 0,9885=0,0108$

Setelah nilai peluang posterior diperoleh dan dicari harga harapan untuk masing-masing alternatif tindakan, hasilnya disajikan pada Tabel 13 
Tabel 13. Hasil Iterasi I Analisis dengan Teorema Bayes.

\begin{tabular}{|c|c|c|c|c|}
\hline \multirow{2}{*}{ Alternatif } & \multicolumn{3}{|c|}{$\theta j$} & \multirow{2}{*}{$\begin{array}{c}\text { HH } \\
\text { (Harga Harapan) }\end{array}$} \\
\hline & 93,07 & 151,72 & 210,37 & \\
\hline Wilayah I & 124,09 & 165,92 & 207,74 & 166,07 \\
\hline Wilayah II & 122,26 & 164,67 & 207,07 & 164,82 \\
\hline Wilayah III & 116,06 & 190,25 & 264,44 & 190,52 \\
\hline Wilayah IV & 91,19 & 144,33 & 197,47 & 144,52 \\
\hline Wilayah V & 65,41 & 93,42 & 121,42 & 93,52 \\
\hline $\mathbf{P}(\theta \mathrm{j})$ & 0,0072 & 0,9820 & 0,0108 & \\
\hline
\end{tabular}

\section{Iterasi IX.}

- $P\left(\theta_{1}\right) \bullet e^{-(0,5)\left\{x-\theta_{1} \mid \sigma\right\}^{2}}=0,0072 \cdot e^{-(0,5)\left\{(151,72-93,07)^{2} / 3439,664\right)}=0,0044$

- $P\left(\theta_{2}\right) \bullet e^{-(0,5)\left\{x-\theta_{2} \mid \sigma\right\}^{2}}=0,9820 \cdot e^{-(0,5)\left\{(151,72-151,72)^{2} / 3439,664\right)}=0,9820$

- $P\left(\theta_{3}\right) \bullet e^{-(0,5)\left\{x-\theta_{3} \mid \sigma\right\}^{2}}=0,0108 \cdot e^{-(0,5)\left\{(151,72-210,37)^{2} / 3439,664\right)}=0,0065$

- $\quad \sum_{j=1}^{3} P\left(\theta_{j}\right) \bullet e^{-(0,5)\left\{x-\theta_{j} \mid \sigma\right\}^{2}}=0,0044+0,9820+0,0065=0,9929$

Besarnya peluang posterior ke-1 adalah: 0,0044 /0,9929 $=0,0044$

Besarnya peluang posterior ke-2 adalah: 0,9820 /0,9929 $=0,9890$

Besarnya peluang posterior ke-3 adalah: 0,0065 /0,9929 $=0,0066$

Setelah nilai peluang posterior diperoleh dan dicari harga harapan untuk masing-masing alternatif tindakan, hasilnya disajikan pada Tabel 14.

Tabel 14. Hasil Iterasi I Analisis dengan Teorema Bayes.

\begin{tabular}{|l|c|c|c|c|}
\hline \multirow{2}{*}{ Alternatif } & \multicolumn{3}{|c|}{$\theta \mathbf{j}$} & $\begin{array}{c}\text { HH } \\
\text { (Harga Harapan) }\end{array}$ \\
\cline { 2 - 4 } & $\mathbf{9 3 , 0 7}$ & $\mathbf{1 5 1 , 7 2}$ & $\mathbf{2 1 0 , 3 7}$ & 166,01 \\
\hline Wilayah I & 124,09 & 165,92 & 207,74 & 164,76 \\
\hline Wilayah II & 122,26 & 164,67 & 207,07 & $\mathbf{1 9 0 , 4 1}$ \\
\hline Wilayah III & 116,06 & 190,25 & 264,44 & 144,45 \\
\hline Wilayah IV & 91,19 & 144,33 & 197,47 & 93,48 \\
\hline Wilayah V & 65,41 & 93,42 & 121,42 & \\
\hline \multicolumn{1}{|c|}{$\mathbf{P}(\boldsymbol{\theta j})$} & $\mathbf{0 , 0 0 4 4}$ & $\mathbf{0 , 9 8 9 0}$ & $\mathbf{0 , 0 0 6 6}$ & \\
\hline
\end{tabular}

Iterasi X.

- $P\left(\theta_{1}\right) \bullet e^{-(0,5)\left\{x-\theta_{1} \mid \sigma\right\}^{2}}=0,0044 \cdot e^{-(0,5)\left\{(151,72-93,07)^{2} / 3439,664\right)}=0,0027$

- $P\left(\theta_{2}\right) \bullet e^{-(0,5)\left\{x-\theta_{2} \mid \sigma\right\}^{2}}=0,9890 \cdot e^{-(0,5)\left\{(151,72-151,72)^{2} / 3439,664\right)}=0,9890$

- $P\left(\theta_{3}\right) \bullet e^{-(0,5)\left\{x-\theta_{3} \mid \sigma\right\}^{2}}=0,0066 \cdot e^{-(0,5)\left\{(151,72-210,37)^{2} / 3439,664\right)}=0,0040$

- $\quad \sum_{j=1}^{3} P\left(\theta_{j}\right) \bullet e^{-(0,5)\left\{x-\theta_{j} \mid \sigma\right\}^{2}=0,0027+0,9890+0,0040=0,9957}$ 
Besarnya peluang posterior ke-1 adalah: 0,0027 /0,9957 $=0,0027$

Besarnya peluang posterior ke-2 adalah: $0,9890 / 0,9957=0,9933$

Besarnya peluang posterior ke-3 adalah: 0,0040 /0,9957 $=0,0040$

Setelah nilai peluang posterior diperoleh dan dicari harga harapan untuk masing-masing alternatif tindakan, hasilnya disajikan pada Tabel 15.

Tabel 15. Hasil Iterasi I Analisis dengan Teorema Bayes.

\begin{tabular}{|l|c|c|c|c|}
\hline \multirow{2}{*}{ Alternatif } & \multicolumn{3}{|c|}{$\theta \mathbf{j}$} & $\begin{array}{c}\text { HH } \\
\text { (Harga Harapan) }\end{array}$ \\
\cline { 2 - 4 } & $\mathbf{9 3 , 0 7}$ & $\mathbf{1 5 1 , 7 2}$ & $\mathbf{2 1 0 , 3 7}$ & 165,98 \\
\hline Wilayah I & 124,09 & 165,92 & 207,74 & 164,73 \\
\hline Wilayah II & 122,26 & 164,67 & 207,07 & $\mathbf{1 9 0 , 3 5}$ \\
\hline Wilayah III & 116,06 & 190,25 & 264,44 & 144,40 \\
\hline Wilayah IV & 91,19 & 144,33 & 197,47 & 93,46 \\
\hline Wilayah V & 65,41 & 93,42 & 121,42 & \\
\hline \multicolumn{1}{|c|}{$\mathbf{P}(\boldsymbol{\theta} \mathbf{j})$} & $\mathbf{0 , 0 0 2 7}$ & $\mathbf{0 , 9 9 3 3}$ & $\mathbf{0 , 0 0 4 0}$ & \\
\hline
\end{tabular}

Setelah dilakukan 10 kali iterasi, maka keputusan yang diambil adalah tetap, yaitu pengembangan rayon Wilayah III dengan harga harapan maksimum 190,35.

\section{KESIMPULAN}

1. Teorema Bayes dapat digunakan dalam pengambilan keputusan untuk merencanakan pengembangan perusahaan pada PT. Asuransi Jiwasraya, karena syarat-syarat terpenuhi, yaitu:

a. Adanya alternatif tindakan yang akan dipilih terhadap lima kantor rayon.

b. Peluang prior adalah peluang kejadian pada kondisi ekonomi yang ada, dan peluang posteriornya adalah jumlah penjualan polis pada lima kantor rayon tahun 2001-2003.

c. Perhitungan dilakukan secara iterasi sampai diperoleh nilai peluang posterior mendekati satu.

2. Keputusan yang diperoleh berdasarkan teorema Bayes dalam merencanakan pengembangan perusahaan pada PT. Asuransi Jiwasraya dengan lima daerah rayon adalah mengembangkan Rayon Wilayah III dengan harapan maksimum sebesar 190,35.

\section{PUSTAKA}

Casella, B., and R.L. Berger. (1990). Statistical Inference, Book/Cole Publishing Company, California.

Levin, R.I., D.S. Rubin, J.P. Stinson, dan E. Garoner. (2002). Quantitative Approaches to Management (Seventh edition), terjemahan oleh Nartanto. PT. Raya Grafindo Pustaka, Jakarta.

Manik, N.I. (2003). Perancangan Program Aplikasi Pengambilan Keputusan Berdasarkan Teorema Bayes, Jurnal Ilmiah MATSTAT, Vol 3. No. 2, UbiNus, Jakarta. 
Markland, R.E., and J.R. Sweigart. (1987). Quantitative Methods: Aplications to Managerial Decision Making. John Wiley \& Sons, New York.

Siagian, P. (1987). Penelitian Operasional: Teori dan Praktek. UI-Press, Jakarta.

Soekarto. (1987). Dasar-dasar Asuransi, Universitas Terbuka Karunika, Jakarta.

Supranto, J. (1988). Riset Operasi Untuk Pengambilan Keputusan, UI-Press, Jakarta.

Walpole, R. (1982). Pengantas Statistika (edisi ketiga), terjemahan oleh Bambang S., PT. Gramedia, Jakarta.

Winston, W.L. (1994). Operations Research: Aplications \& Algorithms. Duxbury Press, California. 